\title{
An exploration of guesthouse fresh produce purchasing behaviour and supply chains in Johannesburg

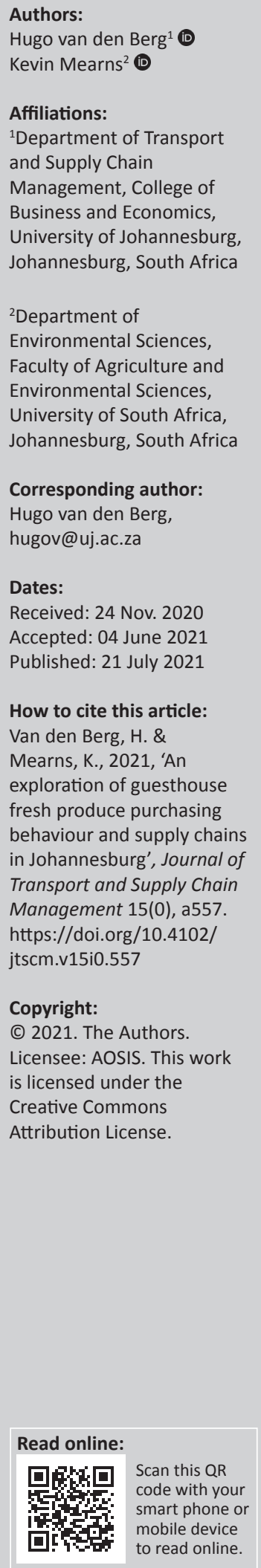

Background: Globally, the challenges of confronting poverty and unemployment continue to dominate the development agenda. The South African government has sought to incorporate local economic development (LED) into their economic development framework. Guesthouses can contribute to LED through procurement of locally produced products and services for their operations.

Objectives: The objective of this article was to determine the fresh produce purchasing behaviour and supply chains of guesthouses in the Greater Johannesburg metropolitan area, and to ascertain their attitudes towards purchasing fresh produce from urban farmers in and around the Soweto area.

Method: A quantitative survey was conducted in the Greater Johannesburg metropolitan area amongst guesthouses in close proximity to the urban farmers in and around Soweto. Qualitative interviews with urban farmers were conducted to ascertain the fruit and vegetable crops propagated in order to attempt to match the supply of urban farmers with the demand of guesthouses.

Results: Several constructive outcomes are obtained. The fresh produce purchasing behaviour of guesthouses in the Johannesburg area is better understood. There is a willingness on the part of guesthouses to change their fresh produce purchasing behaviour. After establishing the fresh produce production in the Soweto area, there are possibilities for matching the fresh produce production with the fresh produce needs of guesthouses.

Conclusion: Although there may be a number of challenges relating to the sale and type of fresh produce from urban farmers to guesthouses in the Johannesburg area, there are possibilities for trade.

Keywords: guesthouses; fresh produce purchasing; purchasing characteristics; urban farmers; changing purchasing behaviour.

\section{Introduction}

The world population at the end of 2019 was approximately 7.7 billion people, 4.3 billion of whom were living in urban areas (United Nations, Department of Economic and Social Affairs Population Dynamics 2020). According to Acuto (2020), because such a large portion of the world's population live in urban areas, food security and food uncertainty have a greater probability of becoming problematic in the future. The coronavirus disease 2019 (COVID-19) has added to global food uncertainty because of global supply chain disruptions. The coronavirus disease 2019 supply chain disruptions represent a new concept, and noticeable problems and difficulties within the food supply chain are surfacing (Singh et al. 2020). The service sector industries - tourism, hospitality, logistical services and education, for example, have experienced major disruptions because of COVID-19 lockdown restrictions. During lockdown, many of the service sector industries have experienced a sizeable decline in the supply and the demand of products, which has led to a decline in production and service delivery, as well as a rise in unemployment.

Currently, service sector industries are faced with an uncertain future because of COVID-19 and lockdown restrictions (Arndt et al. 2020). In a supply chain milieu, there is no standard model that will work for similar types of companies, even if those companies are operating in the same business surroundings (Bos \& Owen 2016; Genovese et al. 2017; Sellitto, Vial \& Viegas 2018). Before COVID-19, the food sector in South Africa was contributing around 2.18\% to the Gross Domestic product (GDP) (Plecher 2020). According to Othman et al. (2018), 
two processes are important for cities to expand: food production and the influx of people into urban areas.

Globally, cities are expanding, and the supply chains that serve the inhabitants of these cities are intensifying the need for resources such as energy, food and water. It is estimated that food supply chains contribute $75 \%$ towards the carbon footprint of food companies (Barros et al. 2018). The carbon footprint linked to the supply and distribution of fresh produce is one of the factors that increases when guests stay overnight in a guesthouse (Toptal \& Çetinkaya 2017). The sourcing of locally produced fresh produce can, therefore, be viewed as a key economic contributor towards the micro-economic environment of a region (Sanches-Pereira et al. 2017).

Othman et al. (2017) define urban farming as agricultural activities positioned within (intra-urban) cities, or on the periphery (peri-urban) of a city, which cultivate fruit and vegetables for human consumption. The possibility of linking up urban farmers to guesthouses within the urban environment could play a mutually beneficial role for the urban farmers and guesthouses that form a part of the tourism industry. Tibane (2019) indicates that the tourism sector contributed 2.8\% (R139 billion) towards the South African real GDP in 2018. This author was of the opinion that projected growth to R145.3b was a possibility in the tourism sector by the end of 2019 - the reason being that guesthouses are accommodation establishments which are a fundamental part of the South African tourism sector. Guesthouses are structured around a family environment which caters for local and international guests in various destinations across South Africa (Ramukumba \& Ferreira 2017). A well-established guesthouse ensures the provision of clean, safe, comfortable accommodation that aims to satisfy the needs of guests.

When a guesthouse understands and realises the benefits of supply chain management (SCM), it should investigate the possibility of including urban farmers in their fresh produce supply chains (Mbenenge \& Thomas 2019; Siregar 2019). Cost factors such as distribution, food packaging and food marketing are incorporated into the final cost of consumers covered when purchasing fresh produce from retail companies (Akaichi, Nayga \& Nalley 2017; Sogari et al. 2017). According to Bazzani and Canavari (2017), the actual distance, or food miles, of the urban farmers' fresh produce is closer to the consumers than the food miles of fresh produce sold by retail companies. Akaichi et al. (2017) agree with Bazzani and Canavari, and state that, besides the greenhouse gases (GHG) emissions linked to fresh produce transportation, the GHG of fresh produce produced by urban farmers are lower than the GHG associated with the GHG of fresh produce which is produced by farmers in rural areas.

Fresh produce coming from rural areas travels further, and the fresh produce is distributed to different retail companies which relates to higher distribution costs and higher GHG emissions. In the supply chain of fresh produce, the final food miles of distribution are regarded as one of the most expensive, least effective and most polluting sections of the supply chain, because it is responsible for the delivery of fresh produce to final consumers (Fancello, Paddeu \& Fadda 2017; Rimawan, Mustofa \& Mulyanto 2017). It is thus possible that the price of fresh produce produced by urban farmers can be lower because of the food miles between the consumers and the urban farmers being fewer (Bazzani \& Canavari 2017).

Through research, it has become clear that no literature is available regarding guesthouses changing their purchasing behaviour through the purchase of fresh produce from urban farmers. Because no literature exists pertaining to guesthouses changing their purchasing behaviour, guesthouses will be able to realise the benefits inherent in changing their purchasing behaviour within the supply chain of fresh produce from urban farmers. The benefits associated with such a change can be the following: (1) a lower purchasing price for fresh produce; (2) a continuous supply of certain fresh produce and (3) the possibility of lower transportation costs (Kartikasari \& Albari 2019; Mbenenge \& Thomas 2019). The owners or managers of guesthouses can decide whether it would be an advantage for the guesthouse if they inform their guests that the guesthouse has included fresh produce from urban farmers in their supply chain.

This article investigates the fresh produce purchasing behaviour of guesthouses in Johannesburg. After the fresh produce purchasing behaviour of guesthouses is determined, the demand can be aligned with the fresh produce produced by urban farmers. This will provide an indication of the possibility that exists for guesthouses to include urban farmers in guesthouses' fresh produce supply chains.

\section{Literature review}

\section{Urban agriculture and guesthouses}

Urban farming, also referred to as Urban Agriculture (UA), is defined as the use of plant cultivation and the breeding of livestock to implement the growing, processing and distribution of food and animal products in and around cities (Fournier 2018). Othman et al. (2017) define urban farming as agricultural activities positioned within (intra-urban) cities, or on the periphery (peri-urban) of a city, which cultivate fruits and vegetables for human consumption. According to Harris and Romero (2019), urban farms can be in various locations within the cities - on rooftops, for example, or in open, abandoned and uninhibited areas. Othman, Latip and Ariffin (2019) go further, stating that urban farming could be a maintainable method of minimising food shortages in an urban community. Mugisa et al. (2017) are of the opinion that urban farming would be able to substitute expensive brand name fruits and vegetables with inexpensive, locally grown fruits and vegetables, thereby strengthening food availability and food security within the city. Poulsen, Neff and Winch (2017) highlight that urban farming can contribute to community rejuvenation through community members participating in cultivating fresh produce. These agricultural activities within an urban farm by community members can 
contribute to the improvement of community cohesion (Gląbiński \& Duda 2017).

When an urban farm is operated successfully, it can be an important component in food security systems which cities can utilise in food security methodologies to 'feed citizens' and fight starvation by providing people with easy access to healthy, fresh produce (Samiullah, Rahman \& Mahmood 2019). In the same way that urban residents can make use of urban farmers for their fresh produce needs, so too can the tourism and hospitality industry take advantage of these alternative sources.

Guesthouses have the ability to acquire their fresh produce from urban farmers in the city, to supply their needs. According to Shi, He and Li (2019), two types of guesthouses exist. The first type is a basic or traditional guesthouse. The focus of these guesthouses is on attributes such as comfort, privacy, cleanliness, economic value, location, efficiency facilities and employee involvement, focusing on customer gratification and satisfaction. The second type of guesthouse is a special or exclusive type of guesthouse. Although this guesthouse also focuses on the same attributes of comfort, privacy, cleanliness, economic value, location, efficiency facilities and employee involvement, focusing on customer gratification or satisfaction, this type offers guests special or exclusive services. These include, for example, personalised excursions to unique and remote tourist destinations. This characteristic and service of the special or exclusive type of guesthouses are similar when compared to high-value hotels (Ju et al. 2019; Kartikasari \& Albari 2019). The guesthouses investigated in this research were all basic and traditional types of guesthouses, all located within the Greater Johannesburg metropolitan area in South Africa.

\section{Supply chain management and guesthouses}

When a guesthouse is operating optimally, the business processes, including the supply chain of the guesthouse, can be considered to be efficient and effective. This refers to the ability of a guesthouse to identify, measure, correct and manage various conundrums within that specific supply chain over a period of time. In supply chain research, the reduction of costs and the minimisation of lead times are important areas of supply chain designs (Babu, Kaur \& Rajendran 2018). With the focus on SCM, new issues such as organisational clarity, security interests and employee benefits, as well as environmental protection, are important emerging research focus areas in the SCM environment (Hong, Zhang \& Ding 2018).

Food supply chains in South Africa are dominated by a handful of large retail organisations, which are labour intensive. Any disruptions in the supply chains of these retail organisations, such as wage negotiations, can disrupt the supply of non-food items as well as fresh produce (Hobbs 2020). Organisations need to adapt and change their current supply chain models to incorporate these emerging research areas. One of the most prominent of these is the trend towards becoming more environmentally friendly (Hong et al. 2018; Yun \& Chuluunsukh 2018). No literature is available, however, regarding guesthouses changing their purchasing behaviour and purchasing fresh produce from urban farmers instead of from retail companies. Supply chain designs are not the only key focus area. Other foci include improving sustainability, reducing waste and increasing responsiveness of local communities and environmental awareness, thus representing alternative outcomes to achieve in supply chain designs (Barbosa-Póvoa, Da Silva \& Carvalho 2018; Nassar et al. 2019). A guesthouse that operates successfully and profitably within a guesthouse supply chain environment is considered effective. It is not merely a lucky strike scenario; rather, it is the combined result of well-planned, well managed processes and procedures in the guesthouse, from the management down to operational level (Darshan \&Teja 2019; Pöiing, Sroka \& Mergenthaler 2017). An efficient and effective supply chain will contribute towards a guesthouse's ability to compete successfully within the accommodation and tourism environment (Babu et al. 2018).

This study focuses on one aspect, namely moving towards achieving a more integrated supply chain for the guesthouse industry by the inclusion of urban farmers into the supply chain of guesthouses. The aim of this research is to determine whether the inclusion of urban farmers into the fresh produce supply chain of guesthouses could increase the efficiency of the fresh produce supply chain, and simultaneously shorten the supply chain of certain fresh produce (Koberg \& Longoni 2019; Legeza et al. 2019). Additional advantages to including urban farmers into guesthouse supply chains are that they will contribute to community involvement and community development, and increase social responsibility through job creation (Bastas \& Liyanage 2018; Xiao et al. 2018).

\section{Fresh produce purchasing behaviour of guesthouses}

Before the potential inclusion of urban farmers into the fresh produce supply chains of guesthouses can be investigated, it is important to firstly understand the current fresh produce purchasing behaviour of guesthouses. Supply chain management has been researched significantly, but no research could be traced pertaining to guesthouse purchasing behaviour of fresh produce from urban farmers. Purchasing behaviour is the preference a person would have for certain products, and this can be influenced by factors such as lifestyle, culture, ethics, tradition, emotional factors and financial factors (Gurbuz \& Macabangin 2019; Šugrová et al. 2018). Apart from the elements mentioned, the purchasing behaviour of consumers is also influenced by product factors such as appearance, convenience, consumer preference, nutritional value and taste.

In a study focusing on the purchasing behaviour of consumers in India residing in the Ernakulam District, Krishnan (2017) reveals that the purchasing power of consumers is changing because of higher education levels, frequent exposure to advertising networks and urbanisation, as well as easy access 
to a variety of supermarkets, hypermarkets and retail stores. Gurbuz and Macabangin (2019) are of the opinion that an elevated demand for a specific product would increase the likelihood that retailers would buy more of that specific product to satisfy the increased demand. However, because of the dearth of information pertaining to guesthouse purchasing behaviour of fresh produce from urban farmers, innovation in fresh produce supply chains could be difficult for guesthouses to explore and implement because of factors such as the following: (1) insufficient knowledge of urban farming; (2) lack of specific fresh produce; (3) supply difficulties; (4) unstable demand and (5) commitment from urban farmers (Hüller, Heiny \& Leonhäuser 2017).

The perceptions of guesthouse owners and managers, in relation to the performance, distribution and effort that guesthouses would have to make in order to purchase fresh produce from urban farmers, would need to be ascertained, in order to determine the likelihood of guesthouses to include urban farmers in their fresh produce supply chains. The first part of the process would be to understand the fresh produce that guesthouses purchase, and secondly, establish where they currently purchase the fresh produce, and how often. The next step would be to find out the kind of fresh produce that urban farmers produce, and whether a possibility exists to match the urban farmers' fresh produce production with the fresh produce needs of guesthouses.

Salladarré et al. (2018) are of the opinion that purchasing agreements should exist between guesthouses and urban farmers, to ensure that the supply chain of quality fresh produce operates on a continuous basis. The aspect of quality produce is also alluded here, and the perceptions of guesthouse owners in relation to the availability of quality produce from urban farmers would also need to be determined. Through research, it appears that the concept of changing purchasing behaviour is one area in the SCM process that has not received a great deal of attention on the part of supply chain managers and researchers (Anjana 2018; Sreedevi \& Saranga 2017).

Furthermore, according to Barros et al. (2018), organisations are working more closely together to incorporate the upstream and downstream supply chain partners. In order to achieve fresh produce supply chain transformation of a guesthouse, systems and procedures need to be in place. The inclusion of urban farmers in the supply chain of a guesthouse can have constructive results, such as reduction in product prices, development of skills within a local community and a growth in revenue for urban farmers (Michailidou et al. 2016; Molefe et al. 2018).

\section{Performance, distribution and effort expectations of guesthouses in terms of urban farmer fresh produce supply}

Determining the perceptions of guesthouse owners, in relation to performance, distribution and effort that it may take guesthouses in the Greater Johannesburg metropolitan area to change their fresh produce purchasing behaviour, is an important focus area in this research (Lorentz et al. 2019). Understanding these perceptions could serve as valuable planning and management tools for the design of structures and processes that may be necessary for the incorporation of fresh produce produced by urban farmers into the guesthouse industry supply chains (Rani \& Ramachandra 2019; Song \& Yu 2018). According to Lorentz et al. (2019), there is a strong relationship between performance expectations and quality, and expectations of guests are met when serving quality fresh produce. The possibility of collaboration between guesthouses in the Greater Johannesburg metropolitan area and urban farmers in and around Soweto could lead to community development and the supply of environmentally acceptable products (Anggita \& Ali 2017).

\section{Research design and methodology}

The research design used in this article was a quantitative survey design. This design was implemented by making use of questionnaires that were completed at 181 guesthouses across the Greater Johannesburg metropolitan area. All the guesthouses that were listed on the following sources received questionnaires: (1) Afristay.com; (2) Room for Africa.com; (3) SA-Venues.com; (4) Sleeping Out.co.za and (5) Where to Stay.co.za. The questionnaire was compiled following literature review findings and consultation with supply chain industry experts. Before the COVID-19 lockdown, guesthouse owners or managers were interviewed, and questionnaires were completed during these interviews.

Guesthouses in the Greater Johannesburg metropolitan area formed the population of this study. The Greater Johannesburg metropolitan area comprised guesthouses within $30 \mathrm{~km}$ of urban farmers in Soweto. It must be noted that the guesthouses interviewed served as the sample for the study of all guesthouses in Gauteng. A questionnaire was used to ascertain the types of fresh produce served during breakfast, as well as to determine from which retailer the fresh produce was purchased. Only breakfasts were selected, because internationally, as well as locally, guesthouses all serve breakfasts.

The intention of the questionnaire was to gain an understanding of the perceptions guesthouse owners or managers have in terms of their purchasing behaviour and the possibility of including urban farmers in their supply chains within the Greater Johannesburg area. The questionnaire made use of closed-ended questions and Likert-scale responses ranging from strongly agree to strongly disagree, and the questionnaire was designed to determine whether guesthouses were willing to change their fresh produce purchasing behaviour. Respondents from guesthouses completed a questionnaire during the period February to March 2020. During the COVID-19 lockdown, respondents from guesthouses and urban farmers were called, and the questionnaires were conducted 
telephonically. A total of 181 guesthouse questionnaires were completed, of which 165 were completed in full, and deemed usable.

The second set of data collection was in the form of telephonic survey interviews with urban farmers. A total of 85 urban farmers were interviewed, to determine the type of fresh produce urban farmers who were growing in and around the Soweto area. At the time of the interview, only four urban farmers indicated that they were selling fresh produce to companies. None of the urban farmers interviewed were selling fresh produce to guesthouses in the Greater Johannesburg metropolitan area. All the urban farmers contacted were part of iZindaba Zokudla, an isiZulu phrase meaning 'conversations about food'. iZindaba Zokudla is the title of a project managed and convened by Dr N. Malan, an academic member of staff at the University of Johannesburg. All the contact details of the urban farmers interviewed were obtained from Dr Malan. It should be noted that the results of the telephonic interviews are but a sample of the urban farmers in Soweto, but the sample does provide a good representation of the urban farmers in Soweto.

\section{Ethical considerations}

The Department of Transport and Supply Chain Management's Research Ethics Committee from the University granted approval with ethical clearance number: 2020 TSCM-0000.

\section{Results}

The results of this study will be dealt with in two sections. The first section covers the results of the interviews with the 165 guesthouses across the Greater Johannesburg metropolitan area, whilst the second section covers the interviews with the urban farmers.

\section{Interviews with guesthouses}

Of the 165 guesthouses interviewed, 53.9\% were in Johannesburg North, $14.6 \%$ in Johannesburg East, $11.5 \%$ in Johannesburg South, $17.6 \%$ in Johannesburg West, whilst $2.4 \%$ were located outside the Greater Johannesburg metropolitan area, but were in close proximity to it. Data collected through the questionnaires revealed that the average age of the guesthouses interviewed was 11.33 years old, varying from 1 to 26 years, indicating that this sector is a well-established sector of the economy. Accommodation reservations in the guesthouses varied from one to seven nights, with the largest portions being two nights (49.1\%) and three nights (20.6\%). These numbers are important, as the implication is that most guesthouses would then prepare at least two meals (breakfasts) during the majority of guest stays. All guesthouses provide breakfast, whilst some provide other meals on request. The number of guests per reservation varied from one to more than six guests: one guest $(22.4 \%)$, two guests $(50.9 \%)$, three guests $(1.8 \%)$, four guests (3\%), five guests (3\%), six guests $(9.7 \%)$ and more than six guests $(9.1 \%)$. This bodes well for urban farmers, as most guests stay from two to three nights, and the size of the reservations indicates that most reservations are made for two or more guests.

The data obtained through the questionnaires from the 165 guesthouses, across the Greater Johannesburg metropolitan area, determined the type of fresh produce these guesthouses primarily require for serving breakfast. The majority (85\%) of guesthouses purchase from retail outlets, whilst $30 \%$ of guesthouses purchase their fresh produce from fruit and vegetable suppliers. The fresh produce products purchased include apples, avocadoes, beetroot, cabbage, chillies, cucumber, kiwifruit, lettuce, mangoes, onions, oranges, pawpaw, pears, pineapples, potatoes, spinach, strawberries and tomatoes. Regarding the frequency of purchasing fresh produce, $63.6 \%$ of guesthouses indicated that they purchase fresh produce once a week, whilst $36.4 \%$ indicated that they purchase fresh produce a few times per week. It is therefore evident that the majority of guesthouses, at the time of the data collection, purchase their fresh produce from retailers once a week. If urban farmers wish to penetrate this market, they would need to have the listed fresh produce products available for purchase at least once a week. This could be facilitated through a weekly urban farmers' market in close proximity to guesthouses.

Guesthouses were asked whether they knew what 'urban farmers' were: $62.4 \%$ confirmed that they knew what urban farmers were, whilst $37.6 \%$ did not have a working knowledge of 'urban farmers'. When guesthouse owners or managers were asked whether they purchased fresh produce from urban farmers, only 12 respondents $(7.3 \%)$ indicated that they infact purchased fresh produce directly from urban farmers. Guesthouses were then asked whether they would be willing to purchase fresh produce from urban farmers. The responses indicated that $34.6 \%$ would be willing to purchase fresh produce from urban farmers, whilst $51.6 \%$ indicated that they might purchase fresh produce from urban farmers, but were not sure. Only $13.7 \%$ of the respondents indicated that they would not be willing to purchase fresh produce from urban farmers.

The guesthouses across the Greater Johannesburg metropolitan area were then asked what their preferred method of payment would be, if they were to buy fresh produce from urban farmers. Only $9.7 \%$ indicated that they would prefer paying cash for their fresh produce, whilst $90.3 \%$ of the guesthouses indicated that they would prefer to make payment by means of electronic funds transfer (EFT). Guesthouses were also asked what their preferred method of communication would be, if they were to purchase from urban farmers. Here again, $90.3 \%$ indicated that they would prefer communicating with urban farmers via social media platforms such as WhatsApp ${ }^{\mathrm{TM}}$, rather than face-to-face.

In order to closely match the demand of fresh produce from guesthouses in the Greater Johannesburg metropolitan area, 
the supply of fresh produce that urban farmers in the Soweto area are producing was ascertained through interviews.

\section{Urban farmer interviews}

Upon site visits to the urban farmers of iZindaba Zokudla, it became evident that the majority planted vegetables, whilst some also planted herbs (such as sage, thyme, parsley, celery, organum). The herbs were planted for resale, as well as for pest control in vegetable gardens. Although the focus of this specific study was on fruits and vegetables for guesthouses, the herbs do present an additional opportunity that guesthouses could utilise to purchase produce from urban farmers. The results indicated that $75.29 \%$ of urban farmers only planted vegetables, $11.76 \%$ plant herbs and vegetables and $12.94 \%$ only planted herbs. The fresh produce produced by the urban farmers is illustrated in Figure 1.

The fresh produce that the farmers produce could be matched with the fresh produce that is purchased by guesthouses, to see if there is a possible match. It is evident from Figure 1 that urban farmers produce eight of the 18 types of fresh produce that guesthouses need, namely beetroot, cabbage, chillies, lettuce, onions, potatoes, spinach and tomatoes. Other fresh produce that could easily be produced by urban farmers includes strawberries and cucumbers.

\section{Discussion}

The results indicate that only a small percentage of guesthouses across the Greater Johannesburg metropolitan area are presently purchasing fresh produce produced by urban farmers. Two important aspects discovered during the study were that: (1) urban farmers need to have facilities to be able to accept EFT payments for fresh produce, and (2) urban farmers would have to use social media platforms to communicate with guesthouses as potential customers. Although only eight of the 18 fresh produce items guesthouses need are presently produced, cucumbers and strawberries could quite easily be produced for the guesthouse market. The urban farmers could, however, through a cooperative agreement, source the missing products from existing wholesale suppliers, or even produce them themselves if they knew that there was a market for it. This would ensure that all the fresh produce demanded

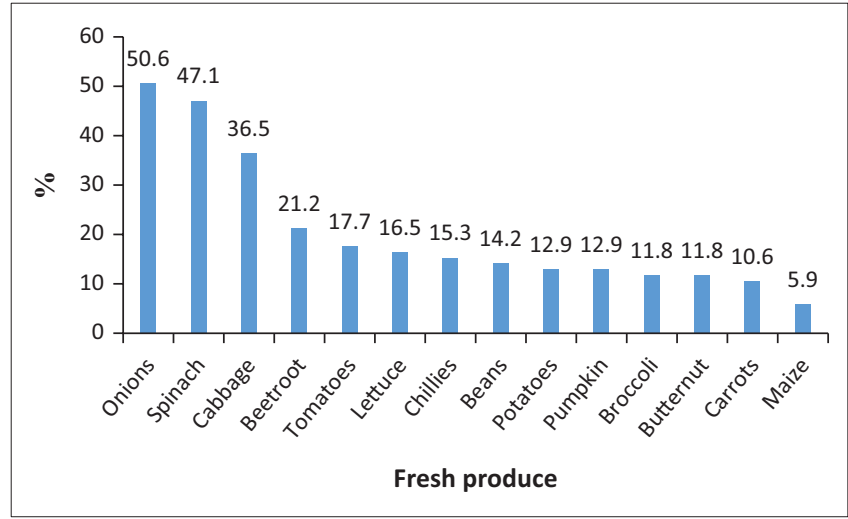

FIGURE 1: Types of fresh produce planted, and percentage of urban farmers who plant different types of fresh produce. by guesthouses could be supplied, making it then a one-stop shop for all the fresh produce needs of guesthouses.

These results indicate that a mutually beneficial relationship between guesthouses and urban farmers could, in the long run, materialise. On the one hand, many guesthouses are not aware of the potential that urban farmers could supply to guesthouses. Guesthouses could change their fresh produce purchasing behaviour to facilitate community development and urban farming in the Soweto area. On the other hand, urban farmers are, in turn, not aware of the demand to produce for guesthouses need in order to cater for their guests. Additional vegetables and other fresh produce such as eggs and chickens could also present additional opportunities for urban farmers to develop a market for their produce. It could be of benefit to guesthouses in the Greater Johannesburg metropolitan area, and also for urban farmers in and around Soweto, to search for opportunities to become part of one another's supply chain, in terms of satisfying the supply and demand for certain fresh produce. The herbs produced by the urban farmers, which was not the focus of this study, could present an additional opportunity for guesthouses to purchase from the urban farmers.

The different interactions between the role players within a supply chain are necessary, in order to create value for all the role players in a supply chain (Hsiao et al. 2018). Evidence of an appropriate framework could not be found for the inclusion of urban farmers in the fresh produce supply chains of guesthouses. The collected data have highlighted some of the essential elements that should be taken into account for the development of an urban farming guesthouse fresh produce supply chain.

\section{Recommendations}

No formal platform exists with information about urban farmers in and around Soweto. Fortunately, with the assistance of iZindaba Zokudla, urban farmers were identified in and around the Soweto area. It is recommended that iZindaba Zokudla compile a complete list of urban farmers in and around the Soweto area, and create a database of the availability of fresh produce they have. Once the data are available, iZindaba Zokudla can create a social media platform through which potential customers - not only guesthouses, but bed-and-breakfast establishments, restaurants and the general public, can have access to the fresh produce available from urban farmers in and around the Soweto area. Another recommendation is to establish an Urban Farmers' Market. The purpose of the market would be to create a platform where urban farmers can sell their fresh produce to consumers on a Saturday, for example.

\section{Conclusion}

It is envisaged that this research will provide a holistic and practical framework to be used by guesthouses, as well as by other formal accommodation establishments, in order to investigate the possibility of including urban farmers in their 
fresh produce supply chains. The research conducted on guesthouses in the Greater Johannesburg metropolitan area demonstrates that guesthouses and urban farmers in and around the Soweto area can fulfil business niches through collaboration and innovative business thinking. As the possibility exists for guesthouses to establish a direct fresh produce supply chain linked to urban farmers, guesthouses may experience cost savings on certain fresh produce that urban farmers produce. Although low-cost specialisation is part of urban farming, it is a business model which can support guesthouses in achieving cost reduction strategies. Urban farming as a whole has the potential to increase a guesthouse's contribution to community involvement and job creation. However, if guests are made aware that fresh produce served in the guesthouse is produced by urban farmers, this sustainability aspect could benefit the guesthouse in the future.

This research provides new insight into the possibility of changing purchasing behaviour, and the possibility of a positive buyer-supplier relationship. The relationship between a guesthouse and an urban farmer can, therefore, have a significant effect on the urban farmer's income, whilst the relationship could have a positive impact on the guests staying at the guesthouse. The academic contribution of this article lies in adding to the continued focus on the relationship between guesthouses in the Greater Johannesburg metropolitan area and urban farmers in and around the Soweto area. The intention of this research is to create greater understanding of creating a possible, and perhaps sustainable, fresh produce supply chain between guesthouses and urban farmers, towards the possible establishment of a more sustainable fresh produce supply chain.

\section{Acknowledgements Competing interests}

The authors have declared that no competing interest exists.

\section{Authors' contributions}

H.v.d.B. and K.M. contributed equally to this article.

\section{Funding information}

The authors declare that no funding was received to conduct the research.

\section{Data availability}

The data that support the findings of this study are available from the corresponding author, H.v.d.B., upon reasonable request.

\section{Disclaimer}

The views and opinions expressed in this article are those of the authors and do not necessarily reflect the official policy or position of any affiliated agency of the authors.

\section{References}

Acuto, M., 2020, 'COVID-19: Lessons for an urban(izing) world', One Earth 2(4), 317-319. https://doi.org/10.1016/j.oneear.2020.04.004

Akaichi, F., Nayga, Jr. R.M. \& Nalley, L.L., 2017, 'Are there trade-offs in valuation with respect to greenhouse gas emissions, origin and food miles attributes?', European Review of Agricultural Economics 44(1), 3-31. https://doi.org/10.1093/erae/ jbw008

Anggita, R. \& Ali, H., 2017, 'The influence of product quality, service quality and price to purchase decision of SGM Bunda milk (study on PT. Sarihusada Generasi Mahardika Region Jakarta, South Tangerang District)', Scholar's Bulletin: A Multidisciplinary Journal 3(6), 261-272.

Anjana, S.S., 2018, 'A study on factors influencing cosmetic buying behavior of consumers', International Journal of Pure and Applied Mathematics 118(9), 453-459.

Arndt, C., Davies, R., Gabriel, S., Harris, L., Makrelov, K., Robinson, S. et al., 2020 'COVID-19 lockdowns, income distribution, and food security: An analysis for South Africa', Global Food Security 26(1), 100410-100414. https://doi. org/10.1016/j.gfs.2020.100410

Babu, D.E., Kaur, A. \& Rajendran, C., 2018, 'Sustainability practices in tourism supply chain', Benchmarking: An International Journal 25(4), 1148-1170. https://doi. org/10.1108/BIJ-06-2016-0084

Barbosa-Póvoa, A.P., Da Silva, C. \& Carvalho, A., 2018, 'Opportunities and challenges in sustainable supply chain: An operations research perspective', European Journal of Operational Research 268(2), 399-431. https://doi.org/10.1016/j. ejor.2017.10.036

Barros, M.V., Da Silva, B.P.A, Piekarski, C.M., Da Luz, L.M, Yoshino, R.T \& Tesser, D.P. 2018, 'Carbon footprint of transportation habits in a Brazilian university' Environmental Quality Management 28(1), 139-148. https://doi.org/10.1002/ Environmental

Bastas, A. \& Liyanage, K., 2018, 'Sustainable supply chain quality management: A systematic review', Journal of Cleaner Production 181, 726-744. https://doi. org/10.1016/j.jclepro.2018.01.110

Bazzani, C. \& Canavari, M., 2017, 'Is local a matter of food miles or food traditions?', Italian Journal of Food Science 29(3), 505-517.

Bos, E. \& Owen, L., 2016, 'Virtual reconnection: The online spaces of alternative food networks in England', Journal of Rural Studies 45, 1-14. https://doi.org/10.1016/j. jrurstud.2016.02.016

Darshan, E.M. \& Teja, B.R., 2019, 'A study on customer purchasing behaviour on durable goods in Kukatpally, Hyderabad', International Journal of Trends in Scientific Research and Development 3(2), 949-952. https://doi.org/10.31142/ ijtsrd21493

Fancello, G., Paddeu, D. \& Fadda, P., 2017, 'Investigating last food mile deliveries: A case study approach to identify needs of food delivery demand', Research in Transportation Economics 65(1), 56-66. https://doi.org/10.1016/j.retrec. 2017.09.004

Fournier, A.J., 2018, 'Direct-selling farming and urban externalities: What impact on product quality and market size?', Regional Science and Urban Economics 70(10), 97-111. https://doi.org/10.1016/j.regsciurbeco.2018.03.001

Genovese, A., Acquaye, A.A., Figueroa, A. \& Koh, S.L., 2017, 'Sustainable supply chain management and the transition towards a circular economy: Evidence and some applications', Omega 66(Part B), 344-357. https://doi.org/10.1016/j. omega.2015.05.015

Gląbiński, Z. \& Duda, T., 2017, 'The local community perception of tourism development: The case of Gryfino County - Western Pomerania, Poland', Bulletin of Geography, Socio-economic Series 37(21), 7-23. https://doi.org/10.1515/bog2017-0021

Gurbuz, M. \& Macabangin, M., 2019, 'Factors affecting consumer's behaviour on purchasing and consumption of food products', Scientific Paper Series Management, Economic Engineering in Agriculture and Rural Development 19(1), 2285-3952.

Harris, D. \& Romero, R., 2019, 'What's a farm? Who's a farmer? Heuristics and city governance of urban farming', Food Studies: An Interdisciplinary Journal 9(4), 21-36. https://doi.org/10.18848/2160-1933/CGP/v09i04/21-36

Hobbs, J.E., 2020, 'Food supply chains during the COVID-19 pandemic', Canadian Journal of Agricultural Economics/Revue canadienne d'agroeconomie 68(2), 171-176. https://doi.org/10.1111/cjag.12237

Hong, J., Zhang, Y. \& Ding, M., 2018, 'Sustainable supply chain management practices, supply chain dynamic capabilities, and enterprise performance', Journal of Cleaner Production 172, 3508-3519. https://doi.org/10.1016/j.jclepro.2017.06.093

Hsiao, Y.-H., Chen, M.-C., Lu, K.-Y. \& Chin, C.-L., 2018, 'Last-mile distribution planning for fruit-and-vegetable cold chains', International Journal of Logistics Management 29(3), 862-886. https://doi.org/10.1108/IJLM-01-2017-0002

Hüller, S., Heiny, J. \& Leonhäuser, I.U., 2017, 'Linking agricultural food production and rural tourism in the Kazbegi District - A qualitative study', Annals of Agrarian Science 15(1), 40-48. https://doi.org/10.1016/j.aasci.2017.02.004

Ju, Y., Back, K.J., Choi, Y. \& Lee, J.S., 2019, 'Exploring Airbnb service quality attributes and their asymmetric effects on customer satisfaction', International Journa of Hospitality Management 77, 342-352. https://doi.org/10.1016/j.ijhm. 2018.07.014

Kartikasari, A. \& Albari, A., 2019, 'The influence of product quality, service quality and price on customer satisfaction and loyalty', Asian Journal of Entrepreneurship and Family Business 3(1), 49-64. 
Koberg, E. \& Longoni, A., 2019, 'A systematic review of sustainable supply chain management in global supply chains', Journal of Cleaner Production 207, management in global supply chains', Journal of Cleane

Krishnan, G.A., 2017, 'Factors affecting the purchasing behaviour of consumers in Ernakulam District with special emphasis on bathing soap', International Journa of Research in Arts and Science 3(Special issue), 11-15. https://doi.org/10.9756/ IJRAS.8150

Legeza, D.G., Brunner, T., Kerimova, Y.K., Kulish, T.V. \& Konovalenko, A.S., 2019, 'A model of consumer buying behavior in relation to eco-intelligent products in catering', Innovative Marketing 15(1), 54-65. https://doi.org/10.21511/ im.15(1).2019.05

Lorentz, H., Laari, S., Engblom, J. \& Tanskanen, K., 2019, 'Attention-based view on achieving ambidexterity in purchasing and supply management', Journal of Purchasing and Supply Management 25(5), 1-11. https://doi.org/10.1016/j. pursup.2019.100560

Mbenenge, M.F. \& Thomas, P., 2019, 'Sustainability practices of Transkei guesthouses', African Journal of Hospitality, Tourism and Leisure 8(4), 21-32.

Michailidou, A.V., Vlachokostas, C., Achillas, C., Maleka, D., Moussiopoulos, N. \& Feleki, E., 2016, 'Green tourism supply chain management based on life cycle impact assessment', European Journal of Environmental Sciences 6(1), 30-36. https://doi.org/10.14712/23361964.2016.6

Molefe, P.L., Tauoatsoala, P., Sifolo, P.P.S., Manavhela, P. \& Henama, U.S., 2018, 'The effects of tourism supply chain management practices on tourism operations in Pretoria, South Africa', African Journal of Hospitality, Tourism and Leisure 7(2), 1-12.

Mugisa, I.O., Fungo, B., Adur, S.O., Ssemalulu, O., Molly, A., Atim, J. et al., 2017, ‘Urban and peri-urban crop farming in Central Uganda: Characteristics, constraints and opportunities for household food security and income', African Journal of Plant Science 11(7), 264-275. https://doi.org/10.5897/AJPS2016.1477

Nassar, S., Kandil, T., Kara, M.E. \& Ghadge, A., 2019, 'Automotive recall risk: Impact of buyer-supplier relationship on supply chain social sustainability', International Journal of Productivity and Performance Management 69(3), 1148-1170. https:// Journal of Productivity and Performance
doi.org/10.1108/IJPPM-01-2019-0026

Othman, N., Latip, R.A. \& Ariffin, M.H., 2019, 'Motivations for sustaining urban farming participation', International Journal of Agricultural Resources, Governance and Ecology 15(1), 45-56. https://doi.org/10.1504/IJARGE.2019.10021353

Othman, N., Latip, R.A., Ariffin, M.H. \& Mohamed, N., 2017, 'Expectancy in urban farming engagement', Environment-Behaviour Proceedings Journal 2(6), 335-340. https://doi.org/10.21834/e-bpj.v2i6.948

Othman, N., Mohamad, M., Latip, R.A. \& Ariffin, M.H., 2018, 'Urban farming activity towards sustainable wellbeing of urban dwellers', IOP Conference Series: Earth \& Environmental Science 117(1), 1-6. https://doi.org/10.1088/1755$1315 / 117 / 1 / 012007$

Plecher, H., 2020, Gross domestic product (GDP) distribution across economic sector South Africa from 2008 to 2018, viewed 25 June 2020, from https://www.statista. $\mathrm{com} /$ statistics/371233/south-africa-gdp-distribution-across-economicsectors/\#statisticContainer.

Pöing, B., Sroka, W. \& Mergenthaler, M., 2017, 'Success of urban farming's cityadjustments and business model - Finding from a survey among farmers in Ruhr Metropolis, Germany', Land Use Policy 69(1), 372-385. https://doi.org/10.1016/j. landusepol.2017.09.034

Poulsen, M.N., Neff, R.A. \& Winch, P.J., 2017, 'The multifunctionality of urban farming: Perceived benefits for neighbourhood improvement', Local Environment 22(11) 1411-1427. https://doi.org/10.1080/13549839.2017.1357686

Ramukumba, T. \& Ferreira, I.W., 2017, 'Sustainable tourism: A view from guest houses in the Eden District municipality', African Journal of Hospitality, Tourism and Leisure 6(1), 1-11.

Rani, N.M. \& Ramachandra, K., 2019, 'A study on consumer perception regarding buying fresh produce in organized retail stores in Bangalore, India: Do demographics matter?', Theoretical Economics Letters 9(8), 2864-2884. https:// doi.org/10.4236/tel.2019.98179
Rimawan, E., Mustofa, A. \& Mulyanto, A.D., 2017, 'The influence of product quality, service quality and trust on customer satisfaction and its impact on customer loyalty (Case study PT ABC Tbk)', International Journal of Scientific \& Engineering loyalty (Case study PT ABC
Research 8(7), 2330-2336.

Salladarré, F., Guillotreau, P., Debucquet, G. \& Lazuech, G., 2018, 'Some good reasons for buying fish exclusively from community-supported fisheries: The case of Yeu Island in France', Ecological Economics 153, 172-180. https://doi.org/10.1016/j. ecolecon.2018.07.017

Samiullah, K.M., Rahman, A. \& Mahmood, S., 2019, 'Evaluation of urban encroachment on farmland: A threat to urban agriculture in Peshawar City District, Pakistan', Erdkunde 73(2), 127-142. https://doi.org/10.3112/erdkunde.2019.02.04

Sanches-Pereira, A., Onguglo, B., Pacini, H., Gómez, M.F., Coelho, S.T. \& Muwang, M.K., 2017, 'Fostering local sustainable development in Tanzania by enhancing linkages between tourism and small-scale agriculture', Journal of Cleaner Production 162(6), 1567-1581. https://doi.org/10.1016/j.jclepro.2017.06.164

Sellitto, M.A., Vial, L.A.M. \& Viegas, C.V., 2018, 'Critical success factors in short food supply chains: Case studies with milk and dairy producers from Italy and Brazil', Journal of Cleaner Production 170(1), 1361-1368. https://doi.org/10.1016/j. jclepro.2017.09.235

Shi, T.T., He, B. \& Li, J.J., 2019, 'Exotic or home? Tourists' perception of guest houses, guest houses loyalty, and destination loyalty in remote tourist destinations', Sustainability 11(14), 3835-3851. https://doi.org/10.3390/su11143835

Singh, S., Kumar, R., Panchal, R. \& Tiwari, M.K., 2020, 'Impact of COVID-19 on logistics systems and disruptions in food supply chain', International Journal of Production Research 1(58), 1-16.

Siregar, S.L., 2019, 'Analysis of effect of price and quality products buying decision against Honda motorcycle at PT. xyz', Enrichment: Journal of Management 10(1), $17-20$.

Sogari, G., Pucci, T., Aquilani, B. \& Zanni, L., 2017, 'Millennial generation and environmental sustainability: The role of social media in the consumer purchasing behaviour for wine', Sustainability 9(10), 1-16. https://doi.org/10.3390/ su9101911

Song, W. \& Yu, H., 2018, 'Green innovation strategy and green innovation: The roles of green creativity and green organizational identity', Corporate Social Responsibility and Environmental Management 25(2), 135-150. https://doi.org/10.1002/ csr. 1445

Sreedevi, R. \& Saranga, H., 2017, 'Uncertainty and supply chain risk: The moderating role of supply chain flexibility in risk mitigation', International Journal of Production Economics 193, 332-342. https://doi.org/10.1016/j.ijpe.2017.07.024

Šugrová, M., Nagyová, L'., Tkáč, F. \& Janšto, E., 2018, 'Factors influencing Slovak consumers' actual buying behaviour towards fresh vegetables', paper presented at the International scientific conference: International scientific days, held in Nitra, the Slovak Republic on May 19-17, 2018, pp. 706-718.

Tibane, S., 2019, South African government: Official guide to South Africa, tourism, viewed 17 September 2020, from https://www.gcis.gov.za/sites/default/files/ docs/resourcecentre/pocketguide/Guide-21-Tourism\%2019-20.pdf

Toptal, A. \& Cetinkaya, B., 2017, 'How supply chain coordination affects the environment: A carbon footprint perspective', Annals of Operations Research 250(2), 487-519. https://doi.org/10.1007/s10479-015-1858-9

United Nations, Department of Economic and Social Affairs Population Dynamics, 2020, World population prospects 2019, viewed 09 September 2020, from https:// population.un.org/wpp/

Xiao, J., Wang, C., Ding, T. \& Akbarnezhad, A., 2018, 'A recycled aggregate concrete high-rise building: Structural performance and embodied carbon footprint' Journal of Cleaner Production 199(1), 868-881. https://doi.org/10.1016/j. journal of Cleaner

Yun, Y. \& Chuluunsukh, A., 2018, 'Environmentally-friendly supply chain network with various transportation types', Journal of Global Tourism Research 3(1), 17-24. https://doi.org/10.37020/jgtr.3.1_17 